\title{
The Roles of Batang Public Hospital, HIV Case Manager, People Living with HIV, Partners, and Peer Support Group, in the Prevention of HIV/AIDS Transmission
}

\author{
Dian Kusumawardani'), Uki Retno Budihastuti²), Mahendra Wijaya3) \\ 1) Academy of Midwifery Harapan Ibu, Pekalongan \\ 2) Department of Obstetrics and Gynaecology, Dr. Moewardi Hospital, Surakarta \\ 3) Faculty of Social and Political Sciences, Sebelas Maret University, Surakarta
}

\begin{abstract}
Background: Batang Public Hospital is one of the referal hospitals for People Living with HIV(PLHIV). It provides outpatient and inpatient care service for PLHIV. Batang Public Hospital is expected to play its role as a referal hospital in collaboration with the HIV case manager to provide a comprehensive care to PLHIV, including mobile Voluntary Counseling and Test (VCT), and facilitating HIV/ AIDS peer support group. The study aimed to investigate the dynamicinteraction between Batang Public Hospital, HIV case manager, VCT nurse, HIV/ AIDS peer support group, and PLHIV, to prevent and control HIV/ AIDS.

Subjects and Method: This was a qualitative study with phenomenology approach, conducted in Batang District, Central Java, Indonesia.Study subjects were selected purposively, which included PLHIV, VCT nurses, Batang Public Hospital administrators, and HIV case manager. The data were collected by in-depth interview.

Result: Batang Public Hospital provides health services with VCT clinics, mobile VCT, PICT (Provider Initiative Counselling and Test), PMTCT (Preventive Mother to Child Transmission). However, PMTCT implementation for birthing mothers with HIV/AIDS is referred to Dr. Karyadi Hospital in Semarang. Batang Public Hospital cooperated with HIV case manager in the implementation of mobile VCT. PLHIV have been participating in the prevention of HIV/AIDS program by using condom.

Conclusion: Batang Public Hospital and HIV case manager have been collaborating in the provision of and health social services for PLHIV. Peer support group provide assistant to PLHIV to improve the quality of life. PLHIV have been participating in the prevention of HIV/AIDS transmission program by using condom and playing their role in the PMTCT program.
\end{abstract}

Keywords: PLHIV,health care, peer support group,health behavior, HIV/AIDS case manager

\section{Correspondence:}

Dian Kusumawardani. Academy of MidwiferyHarapan Ibu, Pekalongan, Central Java.

\begin{tabular}{l}
\hline LATAR BELAKANG \\
\hline HIV/AIDS merupakan fenomena gunung \\
es, dimana data penderita HIV/AIDS yang \\
tampak belum menunjukkan seluruh kasus \\
yang ada. Komulatif kasus HIV dan AIDS di \\
Indonesia dari Januari sampai September \\
tahun 2014 yaitu 22,869 dan prevalensi ka- \\
sus AIDS di Jawa Tengah pada tahun 2014 \\
adalah 11.63 per 100,000 penduduk. Jum-
\end{tabular}

\section{LATAR BELAKANG}

HIV/AIDS merupakan fenomena gunung es, dimana data penderita HIV/AIDS yang tampak belum menunjukkan seluruh kasus yang ada. Komulatif kasus HIV dan AIDS di Indonesia dari Januari sampai September tahun 2014 yaitu 22,869 dan prevalensi kaadal 11.63 per 100,000 penduduk. Jum- lah kumulatif kasus HIV sebanyak 9,032 dan kasus AIDS sebanyak 3,767. (Ditjen PP dan PL Kemenkes RI, 2014).

Kasus HIV/AIDS di Kabupaten Batang menduduki peringkat atas diantara kabupaten atau kota yang berada di Provinsi di Jawa Tengah. Kasus HIV/AIDS di Kabupaten Batang dari tahun 2009-2015 dan ditambah dengan penemuan kasus 
Journal of Health Promotion and Behavior(2016), 1(2): 79-86

https://doi.org/10.26911/thejhpb.2016.01.02.03

baru dari Januari sampai April 2016 sebanyak 649 kasus (Dinkes Batang, 2015).

RSUD Batang sebagai penyedia layanan kesehatan bagi ODHA, merupakan rumah sakit rujukan utama untuk perawatan dan pengobatan ODHA di wilayah Batang berdasarkan Kepmenkes RI No 782/MENKES/SK/IV/2011. Rumah sakit rujukan bagi ODHA hendaknya terintegrasi dengan bagian-bagian lain untuk bisa memberikan layanan komprehensif (Permenkes No 74 Tahun 2014).

Penelitian ini bertujuan untuk mengetahui jenis pelayanan kesehatan ODHA apa saja yang sudah tersedia di RSUD Batang sebagai rumah sakit rujukan ODHA dan media penyuluhan HIV/AIDS yang digunakan.

Jenis pelayanan kesehatan ODHA di fasilitas kesehatan berdasarkan Permenkes No 74 Tahun 2014 antara lain yaitu:

1. PICT (Provider Initiative Conselor Test) adalah konseling dan tes HIV berdasarkan inisiatif pemberi layanan kesehatan kepada seseorang atas dasar kepentingan kesehatan dan pengobatan. Kelompok kunci dalah orang-orang yang beresiko terinfeki HIV, yaitu pekerja seks, pengguna napza suntik, ibu hamil, lelaki seks lelaki, waria, dan transgender.

2. VCT (Voluntary Conselling and Test) adalah konseling dan tes sukarella berdasarkan inisiatif orang yang bersangkutan untuk melakukan rangkaian tes HIV.

3. VCT mobile adalah layanan VCT keliling yang berpindah-pindah dari satu tempat ke tempat yang lain. Pelayanan VCT mobile berguna untuk menjangkau kelompok beresiko terinfeksi HIV namun tidak mau memeriksakan diri ke fasilitas kesehatan (Tamirahayu et al., 2015; De Beer et al., 2015).
4. Pelayanan penunjang yang meliputi pelayanan gizi, laboratorium, perawatan, pencatatan dan pelaporan. Pelayanan gizi pada ODHA berupa pemantauan status gizi, konseling, dan penatalaksanaan gizi. Pelayanan laboratorium berupa pemeriksaan anti HIV, InfeksiOportunistikmikroskopis, menghitung jumlah sel CD4, pemeriksaan viral load HIV, pemeriksaan tes kehamilan, hematologi lengkap, dan pemeriksaan kimia klinik. Perawatan yang dapat diberikan kepada ODHA yaitu rawat jalan, rawat inap, dan perawatan paliatif. Sedangkan pencatatan dan pelaporan berupa kartu pasien, formulir ikhtisar perawatan HIV dan ART, formulir rujukan, formulir registrasi praART, laporan bulanan ART, laporan analisis kohort, serta formulir penggunaan regimen, obat dan stok obat.

Tenaga kesehatan dan non kesehatan yang harus ada di rumah sakit rujukan ODHA berdasarkan Kepmenkes RI No 832/Menkes/SK/X/2006 yaitu dokter umum, dokter spesialis, konselor, perawat, laboran, apoteker, dan manajer kasus. Masing-masing pelaksana pelayanan kesehatan ODHA memiliki kompetensi tertentu yang dapat menunjang pelayanan yang diberikan kepada ODHA. Tenaga kesehatan dan non kesehatan di rumah sakit haruslah memiliki kewaspadaan akan resiko terinfeksi HIV dan penyakit lainnya selama proses dan pasca perawatan pasien.

Kewaspadaan pemberi layanan kesehatan tergantung pada pengetahuan dan keterampilannya dalam proses perawatan (Yassi et al, 2016).

\section{SUBJEK DAN METODE}

Penelitian ini menggunakan metode penelitian kualitatif dengan pendekatan fenomenologi untuk mengkaji secara mendalam jenis-jenis pelayanan kesehatan ODHA 
yang tersedia di RSUD Batang. Peneliti memilih RSUD Batang sebagai tempat penelitian karena meruakan alah satu rumah sakit rujukan ODHA yang ditunjuk oleh Kementerian Kesehatan RI dan terletak di wilayah Kabupaten Batang dengan jumlah orang terinfeksi HIV yang cukup tinggi.

Pemilihan informan utama penelitian dimbil dengan teknik purposive sampling berdasarkan data tenaga kesehatan di RSUD Batang yang sudah mengikuti pelatihan pelayanan kesehatan HIV, serta penentuan jumlah informan utama dan triangulasi menggunakan teknik snowball sampling. Informan utama dalam penelitian ini adalah perawat terlatih yang memberikan pelayanan kesehatan HIV/AIDS. Informan triangulasi yang digunakan dalam penelitian ini adalah manajer kasus HIV dari KPA Batang dan perawat dari bangsal rawat inap RSUD Batang.

Pengumpulan data penelitian dilakukan dengan wawancara mendalam dengan menggunakan pedoman wawancara terstruktur, serta melakukan observasi. Instruemen penelitian yang digunakan adalah pedoman wawancara, lembar observasi, dan peneliti sendiri sebagai human instrument. Selain itu, peneliti menggunakan beberapa alat perekam, seperti recorder, kamera, dan lembar observasi.

Data yang sudah terkumpul diolah melalui tahapan pembuatan transkrip wawancara, membuat koding, mengembangkandan mengaplikasikan analyticalframework, memindahkan data grafik kedalam matriks framework, dan tahapan terakhir adalah menginterpretasikan data (Gale et al, 2013).

\section{HASIL}

RSUD Batang yang ditunjuk sebagai salah satu rumah sakit rujukan ODHA pada tahun 2011 sudah memiliki fasilitas layanan seperti VCT (Voluntary Conselling and Test), CST (Care, Support, and Treatment) secara aktif sebagai pelayanan medis kepada ODHA.

“.....Kalau disini itu ada VCT, CST, kalau PMTCT dulu ada, tapi sekarang paling ya ANCnya saja disini...." (IU.P1)

“......Untuk pelayanan yang terkait dengan pelayanan HIV/AIDS disini ada VCT dan CST. VCTnya ada yang di poli (klinik) dan juga VCT mobile......." (IU.P2)

Fasilitas pelayanan kesehatan tes HIV di RSUD Batang membantu masyarakat untuk mendeteksi dini virus HIV dalam tubuh. Fasilitas laboratorium RSUD Batang juga sudah dilengkapi dengan fasilitas layanan pemeriksaan $\mathrm{CD} 4$ bagi ODHA.

\section{Pelayanan VCT mobile}

Pelayanan VCT mobile RSUD Batang dilaksanakan di daerah lokalisasi, masyarakat umum, dan lembaga pemasyarakatan (Lapas) di Batang dan Kota Pekalongan. Belum tersedianya layanan VCT mobile di Kota Pekalongan menjadi salah satu penyebab Lapas diderah tersebut mengundang tim VCT mobile RSUD Batang untuk melakukan pemeriksaan VCT.

“........VCTnya ada yang di poli (klinik) dan juga VCT mobile. Kalau diklinik kita ada yang VCT ada yang screening. Kalau secara klinis dia sudah mengarah kesana ya kita VCT....... Diluar VCT mobile yang dijadwalkan Dinkes ya, VCT mobile ke Lapas Pekalongan........" (IU.P2).

Pelayanan VCT mobile oleh RSUD Batang bertujuan untuk memperkenalkan adanya pelayanan tes HIV, deteksi dini infeksi HIV dan juga menjaring orang dengan HIV/AIDS yang kemungkinan ber- 
Journal of Health Promotion and Behavior(2016), 1(2): 79-86

https://doi.org/10.26911/thejhpb.2016.01.02.03

ada ditengah-tengah masyarakat, namun belum mengetahui status HIVnya. VCT mobile yang dilakukan ke Lembaga Pemasyarakatan (Lapas) juga bertujuan untuk menjaring adanya infeksi HIV diantara para narapidana.

\section{Pelayanan PICT}

PICT dilaksanakan oleh tenaga kesehatan di RSUD Batang di bangsal rawat inap. Perawat yang bertugas pada malam hari memiliki waktu luang untuk berbincangbincang dengan pasien yang dicurigai sebagai ODHA dan kemudian dilakukan pendekatan untuk melakukan tes HIV.

“.......Kalau pertama datang biasanya kita curiga pada yang bertato, rambutnya di cat, dan latar belakang pekerjaannya......" (IT.RS)

“...........Kalau misalnya ketemu pasien yang panas beberapa hari, terus diare, atau mungkin mereka yang jaga malam ngobrol dengan pasien, pasien mengaku kerja disini-disini-disni, nah itu mereka yang menentukan untuk vct atau gak................. Terus ditemukan ada sedikit faktor resiko dilanjutkan menghubungi petugas VCT......” (IU.P1)

Pelayanan PICT di RSUD Batang dilakukan oleh semua tenaga kesehatan, baik terlatih HIV maupun tidak, sesuai dengan gejala yang dilihat pada pasien. PICT di bangsal rawat inap RSUD Batang biasanya dilakukan oleh perawat dan dokter. PICT dilakukan kepada pasien yang memiliki tattoo, laki-laki bertindik, dan juga kepada orang yang memiliki riwayat pekerjaan sebagai pekerja di kafe karaoke atau pekerja seks komersial.

\section{Pelayanan PMTCT (Prevention Mother to Child Transmission)}

Semua ibu hamil yang melakukan pemeriksaan kehamilan di RSUD Batang wajib untuk melakukan tes HIV. Ibu hamil yang terdeteksi terinfeksi HIV akan segera diberikan terapi ARV (Antiretroviral). Pelayanan antenatal care (ANC) pada ibu hamil dengan HIV tetap dilakukan di RSUD Batang sampai usia kehamilan 31 minggu. Ibu hamil dengan HIV akan dirujuk untuk ANC dan bersalin ke RSUP dr. Karyadi Semarang setelah usia kehamilan memasuki 32 minggu.

“.......kalau PMTCT dulu ada, tapi sekarang paling ya ANCnya saja disini. Persalinannya dirujuk ke RS Karyadi Semarang. Kalaupun ANC disini pun untuk persalinannya kan belum memberikan pelayanannya, jadi sudah di backup dari jauh hari (ANC) udah di Semarang........." (IU.P1).

Pelayanan PMTCT kepada ibu hamil di RSUD Batang dilakukan oleh dokter spesialis obstetri dan ginekologi yang bekerja sama dengan tim CST dalampemberian terapi. Pelayanan ibu bersalin dengan HIV tidak dapat dilakukan di RSUD Batang karena fasilitas kamar operasi yang terbatas dan kesiapan petugas operasi, sehingga persalinan ibu dengan HIV/AIDS dirujuk ke RSUP dr. Karyadi Semarang.

\section{Media penyuluhan HIV/AIDS}

RSUD Batang memberikan penyuluhan tentang HIV/AIDS pada saat melakukan VCT disampaikan secara lisan. Posterposter mengenai orang yang terinfeksi HIV dipasang pada dinding di ruang VCT. Tim VCT mobile yang melakukan sosialisasi ke masyarakat mengenai HIVakan membawa LCD, materi tentang HIV/AIDS, dan perlengkapan laboratorium untuk tes HIV. Namun, tim VCT belum memiliki alat bantu lembar balik tentang HIV/AIDS yang dapat digunakan pada saat memberikan penyuluhan di ruang VCT RSUD Batang.

“.........Kalau ada yang VCT paling ya saya memberikan informasi tentang 
HIV/AIDS itu apa, diberikan secara lisan. Kita belum ada lembar baliknya, paling ya poster-poster yang ditempel di dinding dari dinas........" (IU.P1).

“........Kalo sosialisasi di lapas Pekalongan biasanya sudah tersedia LCD disana, kita tinggal bawa materinya. Tapi kalo di Lapas Batang gak ada (LCD) ya kita bawa sendiri LCD, materi, alat lab dan reagennya. Kalo lembar balik kita gak ada, kita pakainya slide. Kalo gambar aktif kita ada videonya......." (IU.P2).

Media sosialisasi yang digunakan oleh tim VCT mobile RSUD Batang dalam memberikan penyuluhan masih menggunakan tayangan video dan gambar. Namun, konseling HIV di ruang VCT tidak menggunakan media tambahan untuk memantapkan pemahaman klien.

\section{PEMBAHASAN}

RSUD Batang merupakan rumah sakit tipe C milik pemerintah Kabupaten Batang. RSUD Batang sudah memiliki beberapa pelayanan kesehatan, baik untuk rawat jalan maupun rawat inap, kegawatdaruratan, laboratorium, farmasi, radiologi, dan lain sebagainya. RSUD Batang juga ditunjuk sebagai rumah sakit rujukan ODHA sejak tahun 2011, dan saat ini sudah menyediakan pelayanan VCT, CST, layanan ANC untuk ibu hamil dengan HIV/AIDS, serta pengobatan infeksi oportunistik yang menyertai HIV. Pelayanan ibu bersalin dengan HIV/AIDS masih dirujuk ke RSUP dr. Karyadi Semarang karena ketidaksiapan tenaga kesehatan penolong persalinan dan ruangan operasi yang terbatas.

Pelayanan yang diberikan juga dilengkapi dengan tenaga kesehatan yang sudah mengikuti pelatihan penanganan dan pengobatan infeksi HIV. Fasilitas pelayanan kesehatan HIV di RSUD Batang tidak hanya diakses oleh penduduk Kabupaten Batang saja, namun juga digunakan oleh masyarakat dari Kota Pekalongan dan kabupaten-kabupaten sekitarnya (Baroroh et al, 2015).

Pelayanan kesehatan orang dengan HIV/AIDS di RSUD Batang dilakukan oleh tenaga kesehatan yang berkompeten dan sudah sesuai dengan aturan yang ada dalam Kepmenkes RI No 832/Menkes/SK/X/2006. Tenaga kesehatan yang memberikan pelayanan ODHA di RSUD Batang terdiri dari dokter umum, dokter spesialis, perawat, konselor, manajer kasus, tenaga laboratorium, tenaga farmasi/ apoteker, dan tenaga rekam medis. Tenaga kesehatan RSUD Batang yang melayani pelayanan kesehatan ODHA sudah pernah mengikuti berbagai macam pelatihan mengenai HIV/AIDS secara berkelanjutan.

Pemberian terapi ARV kepada ODHA tidak diberikan secara langsung, namun dilakukan uji kepatuhan ODHA terlebih dahulu. Pengujian kepatuhan ODHA untuk mengkonsumsi ARV kurang lebih selama 2 minggu hingga 1 bulan. Jika ODHA dinilai mematuhi nasehat untuk mengkonsumsi ARV secara teratur dan mengambil ARV tepat waktu, maka ODHA tersebut dinilai berhak mendapatkan terapi ARV.

\section{Pelayanan VCT mobile}

Pelayanan VCT di RSUD Batang tidak hanya menetap di poliklinik RSUD, tetapi juga melaksanakan VCT mobile ke daerah di wilayah Batang, Lapas di Batang, dan juga Lapas di Kota Pekalongan. VCT mobile RSUD Batang juga sering dilaksanakan di daerah lokalisasi sesuai dengan jadwal yang sudah disusun oleh Dinas Kesehatan Kabupaten Batang.

Pelaksanaan VCT mobile ke desa atau kelompok masyarakat di Kabupaten Batang 
Journal of Health Promotion and Behavior(2016), 1(2): 79-86

https://doi.org/10.26911/thejhpb.2016.01.02.03

sudah didahului dengan sosialisasi mengenai HIV/AIDS oleh manajer kasus HIV KPA (Komisi Penanggulangan AIDS). Tim VCT mobile RSUD Batang datang untuk melakukan tes HIV jika masyarakat sudah bersedia untuk tes HIV dan berjumlah sekitar 20-30 orang. Pelaksanaan VCT mobile setidaknya dilakukan oleh konselor VCT, manajer kasus, dan petugas laboratorium. Tes darah pada saat VCT mobile menggunakan tes cepat HIV atau Rapid Test.

VCT mobile dilakukan untuk mendekatkan akses pelayanan HIV kepada masyarakat umum di daerah pedesaan dan juga menjangkau kelompok masyarakat tertentu yang beresiko terinfeksi HIV. Pelayanan VCT mobile diketahui meningkatkan keikutsertaan laki-laki untuk melakukan tes HIV, dan meningkatkan keikutsertaan masyarakat untuk tes HIV tanpa harus mengakses fasilitas kesehatan, seperti puskesmas/rumah sakit (Hensen et al., 2014).

\section{Pelayanan PICT}

Pelayanan PICT (Provider Initiative Counselling Test) dilakukan oleh tenaga kesehatan yang bertemu dan merawat pasien di bangsal rawat inap untuk melakukan tes HIV. Tenaga kesehatan biasanya mendekati pasien yang memiliki tattoo, laki-laki bertindik, memiliki riwayat diare dan sariawan dalam waktu lama, serta memiliki latar belakang pekerjaan sebagai pekerja seks komersial. Jika pasien sudah menyetujui untuk melakukan tes, perawat akan melaporkan persetujuan pasien kepada dokter yang bertanggung jawab, untuk kemudian menghubungi petugas VCT dan laboran untuk tes darah. Malatji et al (2015) mengungkapkan bahwa PICT dapat dilakukan tenaga kesehatan untuk menjaring orangorang yang beresiko terinfeksi HIV di rumah sakit, baik di layanan rawat jalan maupun rawat inap, serta menekankan tes
HIV sebagai rutinitas pemeriksaan kesehatan dan upaya deteksi dini.

\section{Pelayanan PMTCT}

Semua ibu hamil di wilayah Batang wajib untuk melakukan tes HIV di semua fasilitas layanan kesehatan, baik fasilitas layanan pemerintah maupun swasta, sesuai dengan Permenkes RI No 51 tahun 2013 tentang pedoman pencegahan penularan HIV dari ibu ke anak. Keikutsertaan ibu hamil dalam programPMTCTakanmeningkatkan keikutsertaan suami untuk melakukan tes HIV (Larson et al, 2012).

Ibu hamil yang terdeteksi terinfeksi HIV di puskesmas wilayah Batang, akan dirujuk untuk melakukan Antenatal Care (ANC) selanjutnya di RSUD Batang agar segera mendapatkan terapi ARV. ANC ibu hamil dengan HIV/AIDS di RSUD Batang dilakukan hingga usia kehamilan kurang dari 32 minggu. ANC ibu hamil dengan HIV/AIDS selanjutnya dirujuk ke RSUP dr. Karyadi Semarang, dengan tujuandokter obstetri ginekologi di rumah sakit rujukan sudah mengenal pasien dan menyiapkan perlengkapan untuk pertolongan persalinan sesuai prosedur PMTCT. Ketidaksiapan rumah sakit dalam pemberian layanan PMTCT secara keseluruhan (sampai ibu bersalin) disebabkan oleh faktor keterbatasan sarana dan prasarana (seperti reagen, obat-obatan, alat kesehatan, ruangan, pemeriksaan laboratorium), masih adanya stigma negatif pada tenaga kesehatan, kurangnya pelatihan, serta belum adanya jaminan kesehatan dan keselamatan bagi tenaga kesehatan pelaksana PMTCT (Lestari dan Susyanti, 2016).

ODHA yang mengikuti program PMTCT pada masa kehamilan dan persalinan berhasil melahirkan dengan sehat dan selamat, bahkan anak dari ODHA memiliki status negatif HIV saat dilakukan tes HIV 
di usia 18 bulan. ODHA mengikuti anjuran dari dokter untuk rutin memeriksakan kehamilan dan mengkonsumsi ARV selama masa kehamilan, serta menjaga kesehatan agar jumlah $\mathrm{CD} 4$ lebih dari 300 selama masa kehamilan. ODHA juga dianjurkan untuk melahirkan dengan operasi caesarea dan tidak memberikan air susu ibu (ASI) kepada bayinya setelah bersalin sebagai salah satu pencegahan penularan HIV, walaupun belum banyak dilakukan penelitian mengenai penularan HIV melalui ASI. Metode yang dilakukan oleh RSUD Batang dalam pencegahan penularan HIV dari ibu ke anak sesuai dengan penelitian Bhisa dan Deo (2015) yang menekankan penggunaan ARV pada masa kehamilan dan menghindari pemberian ASI merupakan caracara yang dapat dilakukan untuk mencegah penularan HIV dari ibu ke anak.

\section{Media penyuluhan HIV/AIDS}

Penggunaan media dalam pemberian informasi atau penyuluhan akan mempermudah pendengar atau penerima informasi untuk mengerti dan memahami isi dari informasi tersebut. Penggunaan bahasa yang mudah dimengerti dan tidak berkesan menakuti dalam pemberian penyuluhan HIV/AIDS akan menarik perhatian dan kesadaran pendengar untuk melakukan deteksi dini HIV dengan melakukan tes HIV secara sukarela (VCT atau Voluntary Counselling Test).

Pelayanan VCT mobile oleh RSUD Batang memberikan sosialisasi kepada masyarakat menggunakan mediaslidepower point yang berisi video dan gambar. Penggunaan media slidepower point yang berisi video dan gambar dalam pemberian pendidikan kesehatan diketahui dapat meningkatkan pengetahuan peserta pendidikan kesehatan. Power point menjadi salah satu media yang digunakan dalam memberikan promosi kesehatan (Wijayanti et al., 2016). Penggunaan media tambahan dalam pemberian sosialisasi atau pendidikan kesehatan, misal dengan gambar dan/atau video, dapat menjadi pelengkap komunikasi yang tidak tersampaikan daripenyampaian lisan.

Pelayanan kesehatan Orang dengan HIV/AIDS (ODHA) di RSUD Batang dapat dilihat dari adanya layanan klinik rawat jalan maupun rawat inap, bagi orang-orang yang ingin melakukan tes HIV maupun sudah terindikasi terinfeksi HIV. Pelayanan klinik HIV meliputi klinik VCT, CST, PICT, dan pemeriksaan ibu hamil dengan HIV/AIDS. RSUD Batang belum melayani pertolongan persalinan pada ibu dengan HIV/AIDS karena keterbatasan kemampuan tenaga kesehatan, ruang operasi, dan obat-obatan. RSUD Batang sebagai rumah sakit rujukan ODHA hendaknya lebih mempersiapkan tenaga kesehatan dan sarana prasarana untuk pelaksanaan PMTCT (Preventive Mother to Child Transmission) secara keseluruhan, sampai pada pertolongan persalinan pada ibu bersalin dengan HIV/AIDS.

\section{DAFTAR PUSTAKA}

Ditjen PP,Pl Kemenkes RI (2014). Statistik Kasus HIV/AIDS di Indonesia Dilapor s/d September 2014.

Dinkes Batang (2015). Profil Kesehatan Kabupaten Batang Tahun 2015. Batang.

Kepmenkes RI(2011). Keputusan Menteri Kesehatan Republik Indonesia Nomor 782/MENKES/SK/IV/2011 tentang Rumah Sakit Rujukan Bagi Orang dengan HIV/AIDS (ODHA). Jakarta: Kementerian Kesehatan RI.

Permenkes(2014). Peraturan Menteri Kesehatan Republik Indonesia Nomor 74 Tahun 2014 Tentang Pedoman Pelak- 
Journal of Health Promotion and Behavior(2016), 1(2): 79-86

https://doi.org/10.26911/thejhpb.2016.01.02.03

sanaan Konseling dan Tes HIV. Jakarta: Kementerian Kesehatan RI.

Tamirayehu T, Tadesse T, Kebede Z (2015). Assessment of the Quality of Mobile VoluntaryCounselingand Testing Services in Addis Ababa and Adama Organization for Social Services for AIDS (OSSA) Branches, Ethiopia. Academic Journals. 8 (4): 36-44.

De Beer I, Chani K, Feeley FG, De Wit TR (2015). Assessing The Costs of Mobile Voluntary Counseling and Testing at The Work Place Versus Facility Based Voluntary Counseling and Testing in Namibia. Rural and Remote Health Research.15: 3357.

Kepmenkes RI (2006). Keputusan Menteri Kesehatan Republik Indonesia Nomor 832/Menkes/SK/X/2006 tentang Penetapan Rumah Sakit Rujukan Bagi Orang dengan HIV/AIDS (ODHA) dan Standar Pelayanan Rumah Sakit Rujukan ODHA dan Satelitnya. Jakarta: Kementerian Kesehatan RI.

Yassi A, Zungu M, Spiegel JM, Kistnasamy B, Lockhart K, Jones D, O'Hara LM, Nophale L, Bryce E, Darwin L(2016). Protecting Health Workers from Infectious Desease Transmission: An Exploration of A Cnadian-South African Partnership of Partnerships. Globalization and Health. 12 (10).

Gale N, Heath G, Cameron E, Rashid S, Redwood S(2013). Using The Framework Method for The Analysis of
Qualitative Data in Multi-Disciplinary Health Research. BMC Medical Research Methodology.13 (117).

Baroroh I, Hidayati N, Kusumawardani D (2015). Pengetahuan dan Sikap Wanita Rawan Sosial Ekonomi (WRSE) tentang Pencegahan Penanggulangan HIV/AIDS di Kota Pekalongan Tahun 2014. Jurnal Litbang Kota Pekalongan. 7(1): 22-39.

Permenkes(2013). Peraturan Menteri Kesehatan Republik Indonesia Nomor 51 Tahun 2013 Tentang Pedoman Pencegahan HIV dari Ibu ke Anak. Jakarta: Kementerian Kesehatan RI.

Larson B, Schnippel K, Ndimbongo B, Xulu T, Brennan A, Long L, Fox MP, Rosen $\mathrm{S}$ (2012). Rapid Pont-of-Care CD4 Testing at Mobile HIV Testing Sites to Increase Linkage to Care: An Evaluation of A Pilot Program in South Africa. J Acquir Immune Defic Syndr. 61 (2): e13-e17.

Bhise JD, Deo D(2015). Awareness and Knowledge of Mother to Child Transmission of HIV/AIDS Among Pregnant Women of Rural Tertiary Care Hospital. Ntl $\mathrm{J}$ of Community Med. 6(4): 491-495.

Wijayanti T, Isnani T, Kesuma AP (2016). Pengaruh Penyuluhan terhadap Pengetahuan tentang Leptospirosis di Kecamatan Tembalang, Kota Semarang Jawa Tengah. BALABA. 12(1): 39-46. 